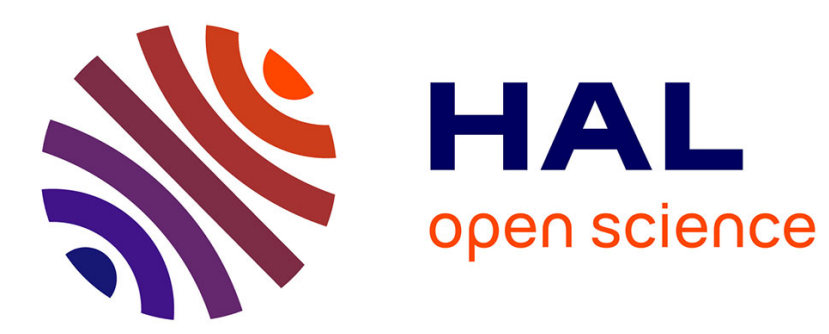

\title{
Fermentation: A Short Scientific and Culinary Overview of Kefir
}

Christophe Lavelle, Jean-Baptiste Boulé

\section{To cite this version:}

Christophe Lavelle, Jean-Baptiste Boulé. Fermentation: A Short Scientific and Culinary Overview of Kefir. Handbook of Molecular Gastronomy, 2021. hal-03320166

\section{HAL Id: hal-03320166 \\ https://hal.science/hal-03320166}

Submitted on 17 Aug 2021

HAL is a multi-disciplinary open access archive for the deposit and dissemination of scientific research documents, whether they are published or not. The documents may come from teaching and research institutions in France or abroad, or from public or private research centers.
L'archive ouverte pluridisciplinaire HAL, est destinée au dépôt et à la diffusion de documents scientifiques de niveau recherche, publiés ou non, émanant des établissements d'enseignement et de recherche français ou étrangers, des laboratoires publics ou privés. 


\section{Kefir: a short scientific and culinary overview}

Christophe Lavelle and Jean-Baptiste Boulé

Genome Structure and Instability, CNRS UMR7196/INSERM U1154, National Museum of Natural History, Sorbonne University, 75005, Paris, France

\section{Introduction}

Fermented foods usually have long storage lives and interesting nutritional values, which makes fermentation a very popular transformation technique all over the world, including for drink production. Among these, kefir is a fermented drink produced by the action of a Symbiotic COmmunity of Bacteria and Yeasts (SCOBY) contained in grains made from a protein and polysaccharide matrix. It is supposed not only to be tasty but also to have many health benefits, including anticarcinogenic, antiviral and antifungal properties, although most of these claims still need further support from medical studies. However, even without sound scientific proof, consumers are generally encouraged by popular media to improve their health through fermented diets that bring a good amount of useful probiotics, making kefir (and other fermented food and beverage) an increasingly fashionable drink (Debailly et al, 2018).

\section{Origin, production and consumption}

Two types of kefir exist today: "milk" and "water" (also called "sugar") kefir.

Milk kefir, thought to have its origins in the north Caucasus Mountains, is still consumed by a lot of Russians. It is traditionally made by inoculating milk (cow, goat or sheep) with kefir grains and keeping it in skin bags at room temperature for a day or more, depending on the conditions and fermentation level desired. The milk kefir grains contain yeasts (including Saccharomyces and Kluyveromyces species) and lactic acid bacteria (including Lactobacillus, Lactococcus, Streptococcus and Leuconostoc species) which produce a viscous, sour, carbonated and slightly alcoholic beverage (Farnworth, 2005; Prado et al, 2015). According to the Codex Alimentarius Standard for Fermented Milks (CODEX STAN 243-2003), milk kefir contains milk protein (> $2.8 \% \mathrm{w} / \mathrm{w})$, milk fat $(<10 \% \mathrm{w} / \mathrm{w})$, titratable acidity expressed as percentage of lactic acid (minimum $0.6 \% \mathrm{w} / \mathrm{w}$ ), ethanol (not stated), and specific microorganisms constituting the starter culture (minimum $10^{7} \mathrm{cfu} / \mathrm{g}$, in total including as a minimum $10^{4} \mathrm{cfu} / \mathrm{g}$ of yeasts).

Water kefir has a more mysterious origin and is not defined by the Codex Alimentarius yet: it might come from the evolution of milk kefir grains cultivated in watery conditions or, as 
sometimes claimed, have appeared spontaneously in the sugar-rich juice of Opuntia cactus. It is made by inoculating a solution of water, sugar and added dry or fresh fruit (usually fig, lemon,...) with kefir grains and keeping for a day or more at room temperature (Fig. 1). The water kefir grains contain yeasts (including Saccharomyces and Candida species) and bacteria (including Lactobacillus, Streptococcus and Leuconostoc species) which also produce a sour, carbonated and slightly alcoholic beverage.

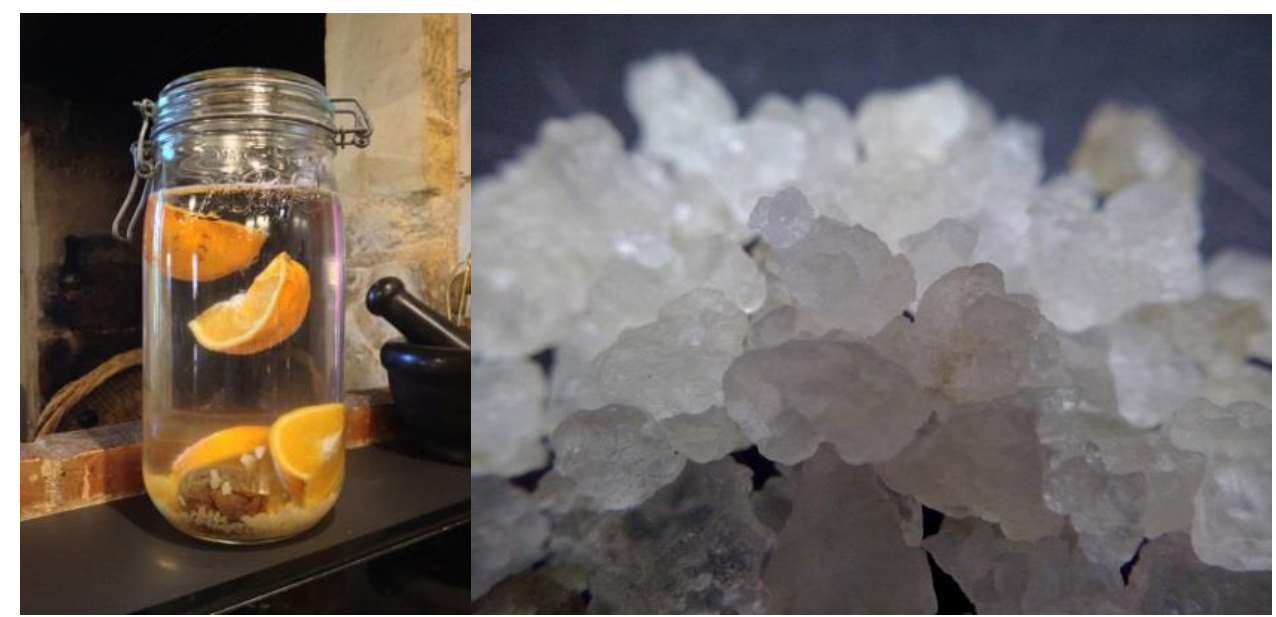

Figure 1: (left) home-made orangelfig water kefir (photo courtesy of Guillaume Stutin); (right) zoom on water kefir grains (each has a few mm in size).

Once strained (to separate the grains from the liquid), kefir drinks can be stored for several days, undergoing a second (slower) fermentation which will enhance the sourness and amount of gas. Water kefir is an increasingly popular drink through the world, mainly due to its ease for production, its alleged health benefits, and the fact that it is suitable for vegans.

\section{Scientific investigations}

The microbial species diversity of water kefir consists of consortium of mainly lactic acid and acetic acid bacteria and yeasts (Fiorda et al, 2017). Microbial analysis of kefir samples taken from different locations worldwide show differences in microbiological populations, which reflect the colonization of culture by some opportunistic yeasts and bacteria found in the environment (Gulitz et al, 2011; Laureys and De Vuyst, 2014).

We collected about 100 different kefir grains in our lab and started a thorough biochemical (using controlled fermentation; Fig. 2) and microbiological analysis (through metagenomics; fig. 3) of 
each of them. The goal of this ongoing study is to show (1) the link between the microbiological content (bacteria, yeasts) and the physiological/sensory parameters (metabolites, taste) of the drink and (2) the high diversity of kefir.
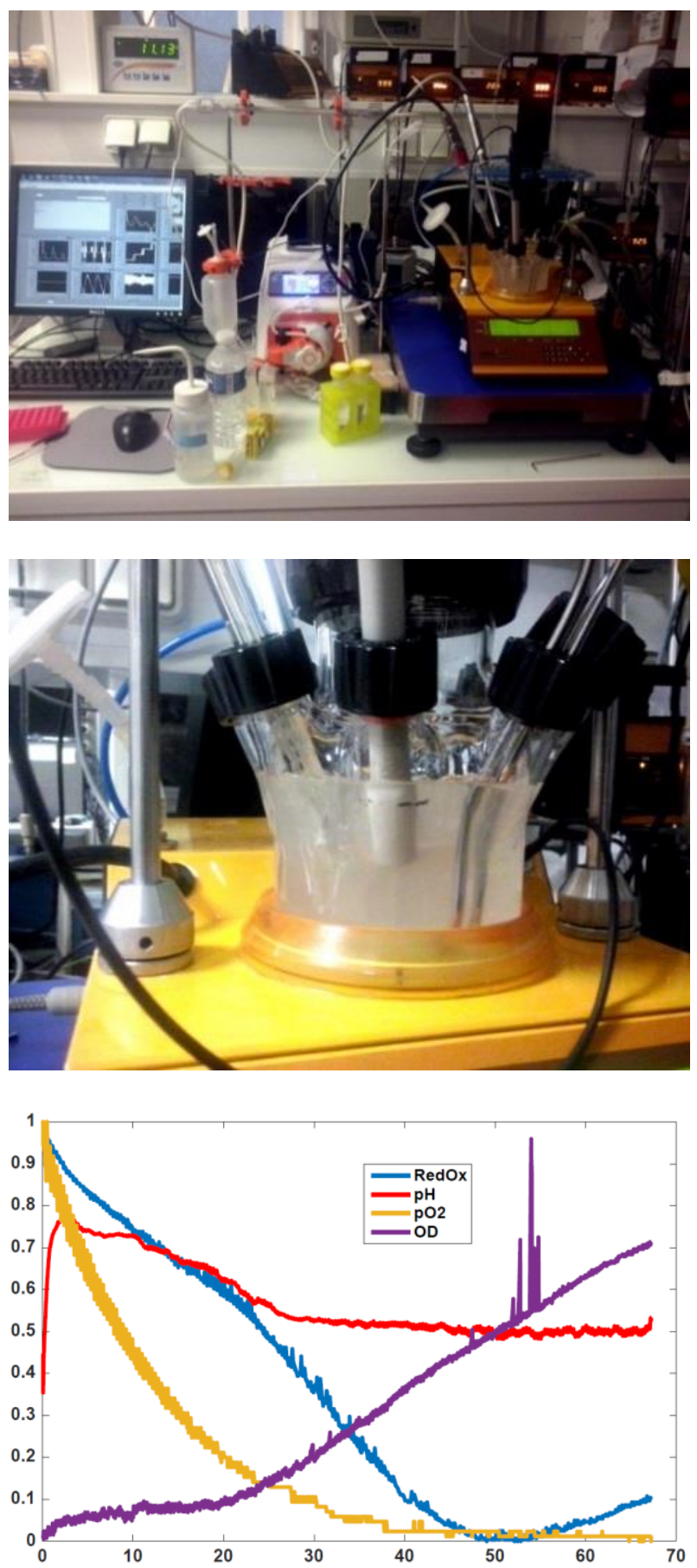

Figure 2: water kefir grown in laboratory conditions. Various parameters are measured, including optical density, $\mathrm{pH}$, RedOx and pO2 (y-axis, normalized units) during the time of fermentation (x-axis, hours).

Previous studies have already shown that sucrose is mainly converted into ethanol, lactic acid (which gives the sour taste), polysaccharides (that create new matrix for the grains), and, to a lower 
extent, glycerol, acetic acid, and mannitol (Laureys and De Vuyst, 2014). More studies are needed to address many unanswered questions such as the influence of various parameters (light, oxygen, ingredients added, liquid/grains ratio, etc.) on the final result, as well as testing some "fancy" statements (never use metal tools, never use white sugar, etc.) often found in popular papers and social media (Debailly et al, 2018).

Regarding the microbial composition, some studies have pointed out the differences between kefir strains (Nalbantoglu et al, 2014), making it difficult to characterize what a "standard" kefir could be. Indeed, we found totally different profiles in our collection, with major species varying from one strain to the other (Fig. 3). Again, further studies are needed to rich a more complete "landscape" of what kefir is (or, indeed, are)!
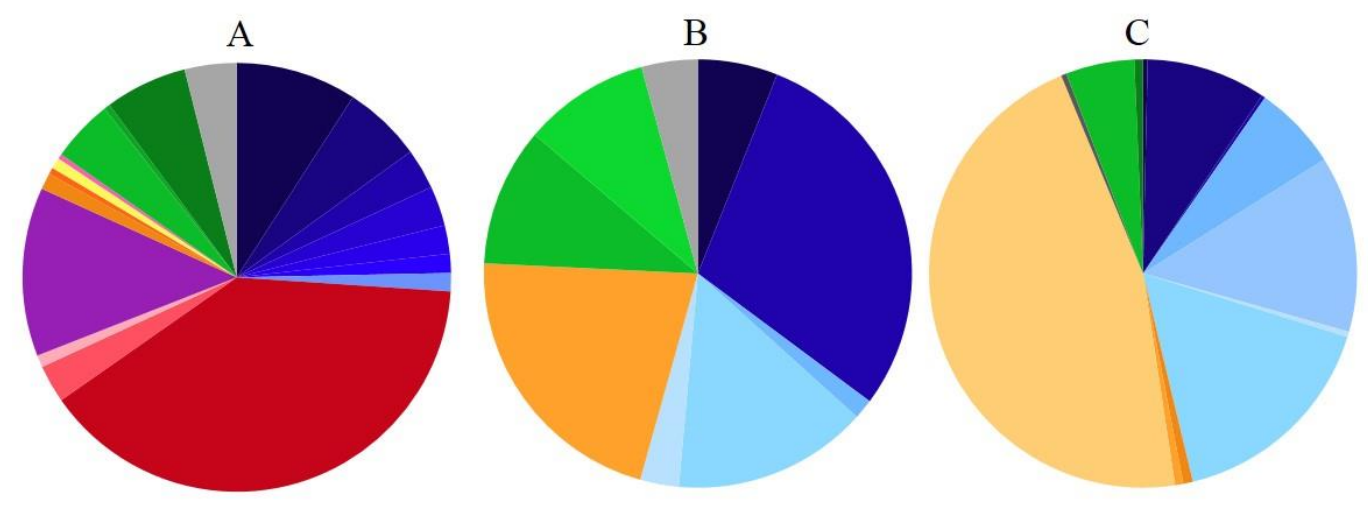

Figure 3: genomic profile of 3 different kefirs. Each strain shows a different composition, with more than a dozen of identified species, among which some dominant like Bifidobacterium aquikefiri (red) for kefir A, Leuconostoc mesenteroides (orange) and Lactobacillus ghanensis (dark blue) for kefir B and Oenococcus kitaharae (beige) for kefir C. Yeast (mainly Saccharomyces species, various greens) are present in the 3 strains. Courtesy Alexandra Joubert, Genome Structure and Instability unit.

Biochemical, metagenomic and metabolomic studies provide evidence of the large number of microorganisms in starting strains and the variety of possible bioactive compounds that could be formed during fermentation, and have to be followed by medical/clinical studies aimed at characterizing the potential health effects of a regular kefir consumption (Farnworth, 2005; LopitzOtsoa et al, 2006). This is especially true for water kefir, for which fewer studies exist compared to milk kefir (Fiorda et al, 2017).

\section{Culinary uses}


As said before, we don't need to wait for medical studies to enjoy kefir for its taste! If milk kefir has been traditionally used for a long time in various recipes from former Soviet Union countries (mainly in soups like cold bortsch and okrochka), more recently water kefir has also become quite popular among chefs, who start using it in various preparations (breads, sauces, sorbets,...) or directly serving it as drinks to accompany the meal as a way to replace wine in food/drink pairing menus. This is probably the perfect occasion for collaborative work between cooks and scientists!

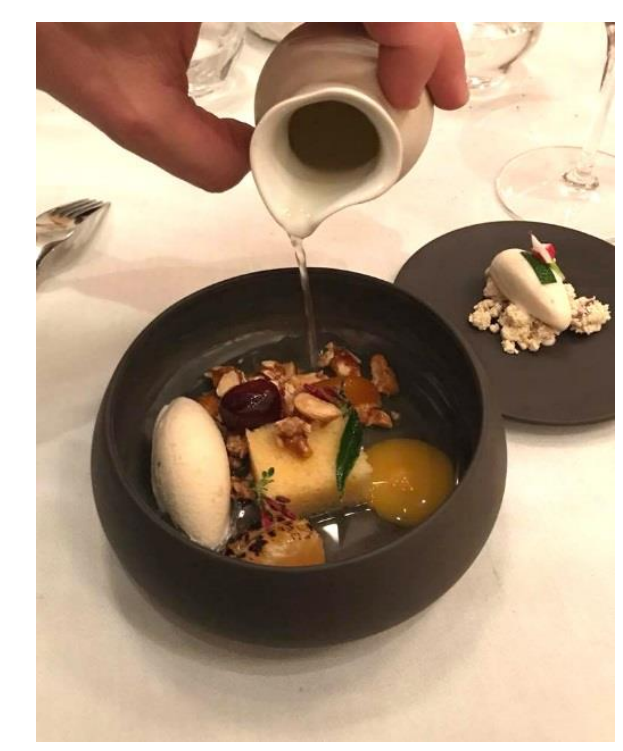

Figure 4: kefir is more and more used in restaurants; here it is seen on a dessert at Flaveur restaurant in Nice, France (photo courtesy of Sylvain Erhardt)

\section{Acknowledgements}

We thank Pierre Renault (MICALIS-INRAE, Jouy-en-Josas, France) for collaboration on metagenomics studies. Work at the Genome Structure and Instability unit is supported by CNRS, INSERM and MNHN.

\section{References}

Debailly R, Lavelle C and Schultz E. 2018. Conserver un aliment vivant. Entretien et circulation d'un ferment : le cas du Kéfir. Techniques et Culture "Le temps des aliments" Nº9:180-183.

Farnworth ER. 2005. Kefir - a complex probiotic. Food Science and Technology Bulletin: Functional Foods 2:1-17.

Fiorda FA, de Melo Pereira GV, Thomaz-Soccol V, Rakshit SK, Pagnoncelli MGB, Vandenberghe LPS, Soccol CR. 2017. Microbiological, biochemical, and functional aspects of sugary kefir fermentation - A review. Food Microbiol 66:86-95. 
Gulitz A, Stadie J, Wenning M, Ehrmann MA and Vogel RF. 2011. The microbial diversity of water kefir. International Journal of Food Microbiology, 151(3), 284-8.

Laureys D and De Vuyst L. 2014. Microbial Species Diversity, Community Dynamics, and Metabolite Kinetics of Water Kefir Fermentation. Appl Environ Microbiol. 80(8): 2564-2572.

Lopitz-Otsoa F, Rementeria A, Elguezabal N, Garaizar J. 2006. Kefir: a symbiotic yeasts-bacteria community with alleged healthy capabilities. Rev Iberoam Micol. 23(2):67-74.

Nalbantoglu U, Cakar A, Dogan H, Abaci N, Ustek D, Sayood K and Can H. (2014). Metagenomic analysis of the microbial community in kefir grains. Food Microbiol 41:42-51.

Prado MR, Blandón LM, Vandenberghe LPS, Rodrigues C, Castro GR, Thomaz-Soccol V and Soccol CR. 2015. Milk kefir: composition, microbial cultures, biological activities, and related products. Frontiers in Microbiology, 6. 